\title{
The Identification of an Uncommon Dermatophyte as an Agent of Tinea Corporis, Microsporum Ferrugineum Tinea Corporis'in Nadir bir Etkeni olarak Microsporum Ferrugineum'un İdentifikasyonu
}

\author{
${ }^{1}$ Iman Qoraan, ${ }^{1}$ Yasemin Öz, ${ }^{2}$ Iş11 Bulur \\ ${ }^{1}$ Eskisehir Osmangazi University Faculty of Medicine, Department of Microbiology, Eskisehir, Türkiye \\ ${ }^{2}$ Eskisehir Osmangazi University Faculty of Medicine, Department of Dermatology, Eskisehir, Türkiye
}

\begin{abstract}
A case of 29 years old female who admitted to Eskisehir Osmangazi University Hospital of Medical Faculty, Dermatology Clinic because of ringworm skin rashes resembling tinea corporis has been represented in this paper. Hyaline septate branching hyphae were seen in microscopic examination of skin scrapping specimens and the agent grown on Sabouraud dextrose agar (SDA) and mycobiotic agar including cycloheximide and chloramphenicol after four weeks. Based on its microscopic characteristics and the results of several phenotypic tests such as frequent reflexive hyphae formation on corn meal tween 80 agar, yellow pigment production on Lowenstein Jensen agar, positive urease test in Christensen urea broth and failure to grow at $37^{\circ} \mathrm{C}$ on SDA, the isolate was identified as Microsporum ferrugineum which share similar macroscopic characteristics with dysgonic strains of other dermatophytes. Topical sertaconazole nitrate implementation was started for treatment and clinical and mycological response was observed after one month.
\end{abstract}

Key words: Dermatophytes, Tinea corporis, Microscopic characteristics, phenotypic tests

Qoraan I., Öz Y., Bulur I. (2017). The Identification of an Uncommon Dermatophyte as an Agent of Tinea Corporis, Microsporum Ferrugineum, Osmangazi Journal of Medicine, 39(2):70-74. DOI: 10.20515/otd.330021.

Öz: $\mathrm{Bu}$ makalede tinea corporisi düşündüren halka şeklindeki cilt döküntüleriyle Eskişehir Osmangazi Üniversitesi Tıp Fakültesi Hastanesi, Dermatoloji Kliniği’ne başvuran 29 yaşında bir kadın olgu sunulmuştur. Hastanın cilt kazıntı örneklerinin mikroskobik incelemesinde dallanan septalı hifler görüldü ve dört hafta sonunda etken Sabouraud dekstroz agar (SDA) ve sikloheksimid ve kloramfenikol içeren mikobiyotik agarda üredi. Mikroskobik özellikleri ve misır unlu tween 80 agarda sık refleksif hiflerin oluşumu, Löwenstein Jensen agarda sarı pigment üretimi, Christensen üre besiyerinde pozitif üreaz testi ve SDA'da $37^{\circ} \mathrm{C}^{\prime}$ de üreme yetersizliği gibi birkaç fenotipik test sonucuna dayanılarak izolat, diğer dermatofitlerin disgonik kökenleri ile benzer makroskobik özellikleri paylaşan Microsporum ferrugineum olarak tanımlandı. Tedavi amacıyla topikal sertakonazol nitrat başlandı ve bir ay sonra klinik ve mikolojik yanıt gözlendi.

Anahtar kelimeler: Dermatofitler, Tinea corporis, mikroskobik özellikler, fenotipik testler

Qoraan I., Öz Y., Bulur I. (2017). Tinea Corporis'in Nadir bir Etkeni olarak Microsporum Ferrugineum'un İdentifikasyonu, Osmangazi Tip Dergisi, 39(2):70-74. DOI: 10.20515/otd.330021. 



\section{Introduction}

Dermatophytes are a group of organisms that are able to break down keratin in tissues such as epidermis, hair and nails. Some of these organisms are anthropophilic that are adapted to humans and usually transmitted from person to person. Others are zoophilic species that adapted to animals. A few strains are geophilic species which live normally in the environment but could cause infections to both humans and animals. There are three main groups of dermatophytes that typically cause superficial infections of different parts of the body; Epidermophyton, Trichophyton and Microsporum. Skin infections could be caused by the majority of dermatophytes though it is mostly caused by Trichophyton rubrum (1). Although dermatophytes are widely distributed in different areas of the world, some species are known to be endemic in certain areas.

\section{Case Report}

A 29 year old female was referred to Eskisehir Osmangazi Dermatology Clinic for a number of skin rashes involved the abdomen and chest resembling tinea corporis ringworms. Patients' history revealed that the lesions were seen after contact with a fungus infected cat and for treatment she had used imidazole ointment for a few days without improvement. Skin scrapings were collected from the borderline of these lesions and sent to our mycology laboratory for examination. Microscopic examination with $15 \% \mathrm{KOH}$ of these specimens revealed hyaline septate branching mycelium with several arthroconidia. The specimen was cultured on Sabouraud dextrose agar (SDA) and mycobiotic agar and incubated aerobically at $30{ }^{\circ} \mathrm{C}$ for four weeks. Glabrous, wrinkled, yellow to cream colored, reverse yellow to light brown colonies yielded after two weeks (Figure 1). We did not detect macro or microconidia by microscopic examination with lactophenol cotton blue. Irregular branching hyphae with prominent cross walls or bamboo hyphae, frequent chlamydoconidia and racket hyphae were seen (Figure 2).

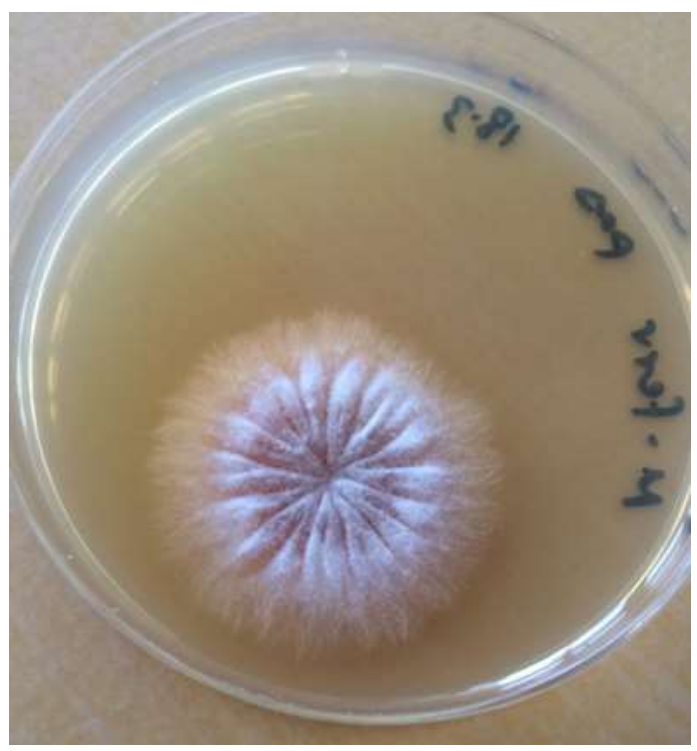

Front

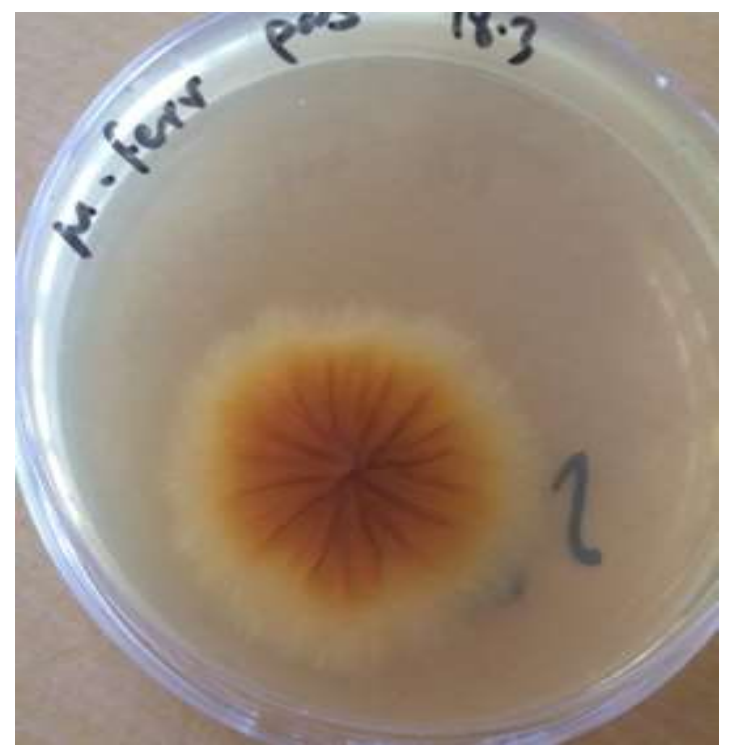

Back

Figure 1. Colony of Microsporum ferrugineum on SDA after two weeks 

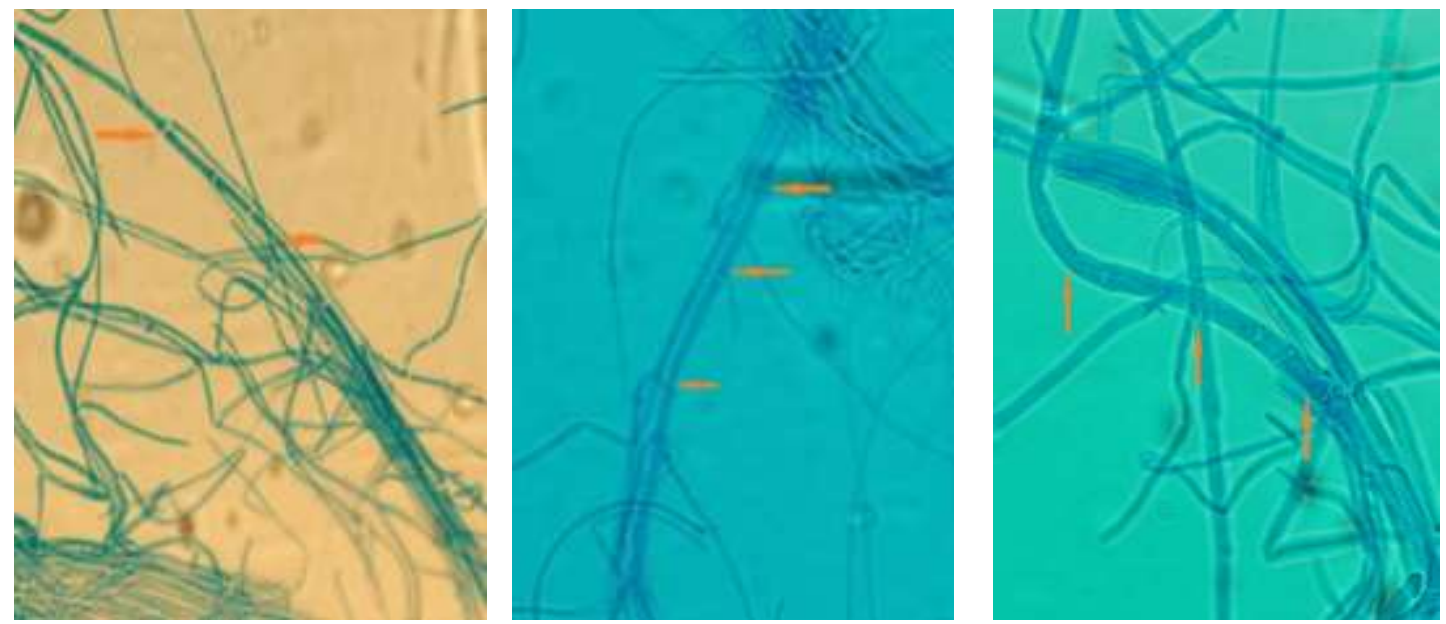

Figure 2. Bamboo hyphae formation in microscopic examination with lactophenol cotton blue (X400 magnification)
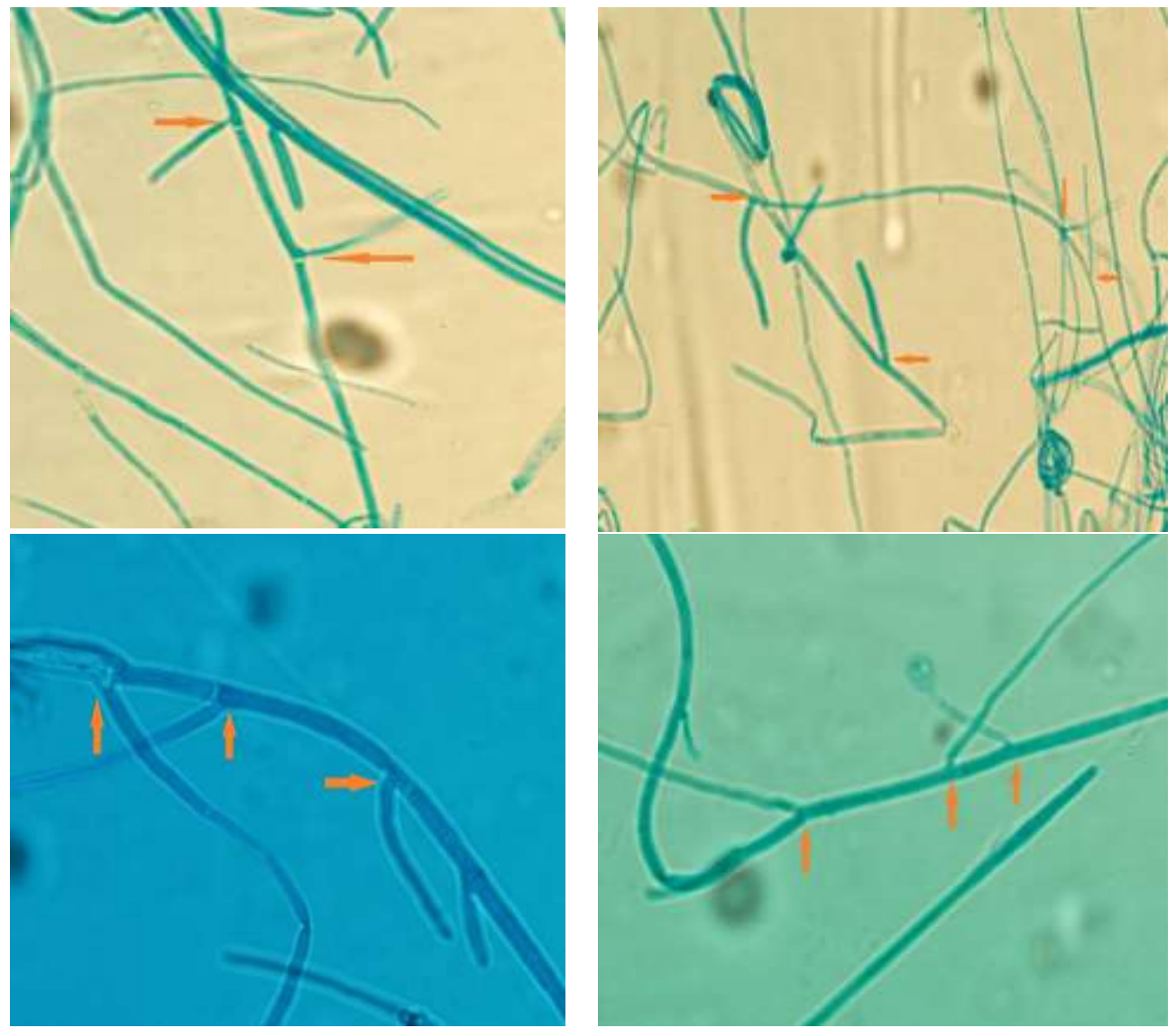

Figure 3. Reflexive hyphae in microscopic examination with lactophenol cotton blue (X400 magnification). 


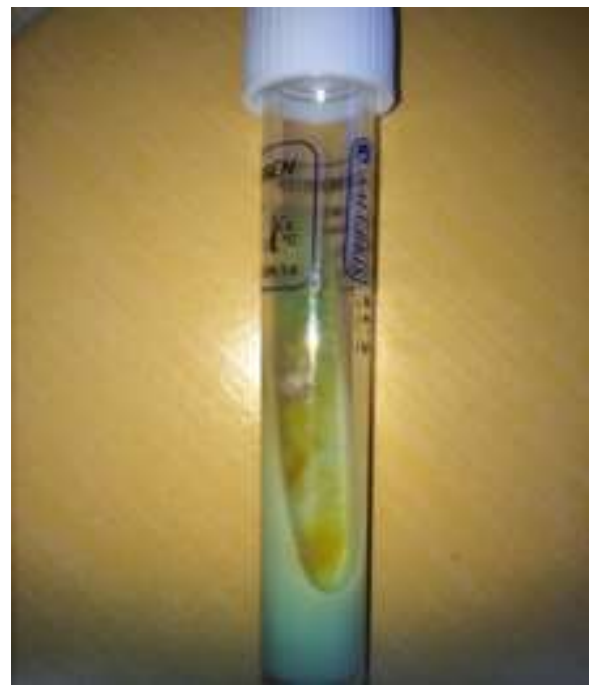

Figure 4. Yellow pigment production on Löwenstein Jensen agar

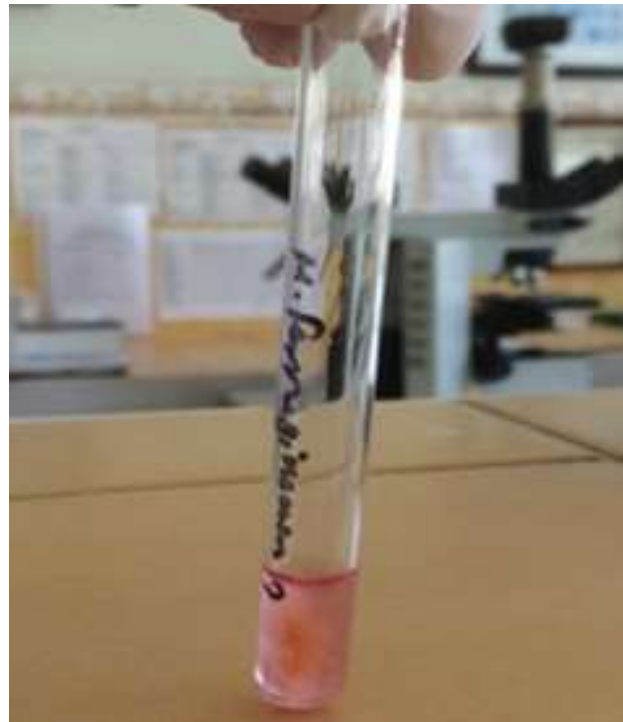

Figure 5. Positive urease test in Christensen urea broth

\section{Discussion}

Microsporum ferrugineum is an anthropophilic dermatophyte and endemic in areas such as Balkans, Middle East, East Asia and Nigeria; sporadic cases have been reported from other parts of the world (2-4). It is mostly reported as a cause of juvenile tinea capitis. Rare cases of tinea corporis caused by this dermatophyte were reported (5). Microsporum ferrugineum is phylogenetically similar to dysgonic strains of Microsporum canis and Microsporum audouinii (6). Routine identification of this species is determined by evaluating its growth on SDA with cycloheximide and chloramphenicol or on potato dextrose agar. The most prominent feature in its microscopy is the presence of bamboo hyphae or hyphae with cross walls (2). Other features like frequent chlamydospores, racket hyphae are commonly present though macroconidia or microconidia could not be seen (7). Frequent chlamydospores, absence of both macroconidia and microconidia, in addition to macroscopic characteristics of the growing species are shared commons of $M$. ferrugineum, $M$. audouinii and dysgonic strains of $M$. canis. The first two fungi species are anthropophilic while $M$. canis is zoophilic (7). The source of the infection could be the infected cat and the isolate could be more related to $M$. canis dysgonic type; however, the presence of bamboo hyphae concluded that the infection was mostly caused by $M$. ferrugineum. The species also showed reflexive hyphae after growing on corn meal tween 80 agar which was a common feature of 
Trichophyton soudanense. These two species are differentiated using broth urease test, pigment production using Löwenstein Jensen agar and growth at $37{ }^{\circ} \mathrm{C}(8)$. Positive urease test, production of yellow pigment instead of brown-black and failure to grow at $37^{\circ} \mathrm{C}$ had also confirmed that the species causing infection was M. ferrugineum.

As a result, $M$. ferrugineum as uncommon causative agent of tinea corporis could share common characteristics with other phylogenetically related dermatophytes in addition to other unrelated species; its routine identification could be difficult though we managed to identify this species depending on its common features. However, this phenotypic identification results should be confirmed by molecular methods for accurate identification. In conclusion, dermatophytes may exhibit unusual morphologic features the fact that requires several physiologic and chemical identification tests besides their morphologic characteristics for their correct identification.

\section{REFERENCES}

1. Havlickova, B., Czaika, V.A., Friedrich, M. (2008). Epidemiological trends in skin mycoses worldwide. Mycoses, 51(4), 2-15.

2. Kane, J., Summerbell, R.C., Sigler, L., Krajden, S., Land, G. (1997). Laboratory Handbook of Dermatophytes. Belmont, USA: Star Publishing Company.

3. Weitzman, I., Summerbell, R.C. (1995). The dermatophytes. Clin Microbiol Rev., 8, 240-259.

4. Wisuthsarewong, W., Chaiprasert, A., Viravan, S. (1996). Outbreak of Tinea capitis caused by Microsporum ferrugineum in Thailand. Mycopathologia, 135, 157-161.

5. Jung, H.D., Chi, S.G., Lee, W.J. Jun, J.B., Suh, S.B., Bang, Y.J., Kim, B.S., Lee, S.J., Kim, D.W.
(2008). A Case of Tinea Corporis Caused by Microsporum ferrugineum. Korean J Med Mycol., 13(1): 37-40.

6. Gräser, Y., Scott, J., Summerbell, R. (2008). The new species concept in dermatophytes-a polyphasic approach. Mycopathologia, 166 (5-6): 239-256.

7. Ellis, D., Davis, S., Alexiou, H., Handke, R., Bartley, R. (2007). Descriptions of Medical Fungi, $2^{\text {nd }}$ ed., Mycology Unit Women's and Children's Hospital, North Adelaide, Australia.

8. Weitzman, I., Rosenthal, S. (1984). Studies in the differentiation between Microsporum ferrugineum Ota and Trichophyton soudanense Joyeux. Mycopathologia, 15; 84(2-3): 95-101. 